\title{
Degradation of Lignocelluloses Cocoa Shell (Theobroma cacao L.) by Various Types of Mould Treatments
}

\author{
Mohamad Djali $\mathbb{D}^{1},{ }^{1}$ Indira Lanti Kayaputri $\left(\mathbb{D},{ }^{1}\right.$ Dian Kurniati ${ }^{D},{ }^{1}$ Een Sukarminah, \\ Inna Muslimah Hanifa Mudjenan, ${ }^{1}$ and Gemilang Lara Utama $\mathbb{\circledR}^{1,2}$ \\ ${ }^{1}$ Faculty of Agro-Industrial Technology, Universitas Padjadjaran, Sumedang, Indonesia \\ ${ }^{2}$ Centre for Environment and Sustainability Science, Universitas Padjadjaran, Bandung, Indonesia \\ Correspondence should be addressed to Gemilang Lara Utama; g.l.utama@unpad.ac.id
}

Received 15 September 2021; Revised 7 November 2021; Accepted 13 November 2021; Published 29 November 2021

Academic Editor: Chunpeng Wan

Copyright (c) 2021 Mohamad Djali et al. This is an open access article distributed under the Creative Commons Attribution License, which permits unrestricted use, distribution, and reproduction in any medium, provided the original work is properly cited.

\begin{abstract}
Lignocellulose can be degraded by lignocellulolytic microorganisms such as moulds. The purpose of the study was to obtain the right type of moulds in degrading lignocellulose on the cocoa shell powder. The study used a completely randomized design method using four treatments of different types of mould (Trichoderma viride, Neurospora sitophila, Aspergillus niger, and Rhizopus oryzae) towards cocoa shell powder fermentation. Solid fermentation of cocoa shell powder was carried out for 5 days in an incubator with a temperature of $30^{\circ} \mathrm{C}$ for $T$. viride, $N$. sitophila, and $R$. oryzae, while A. niger of $35^{\circ} \mathrm{C}$. The fermented substrate was then dried in a cabinet oven with a temperature of $50^{\circ} \mathrm{C}$ for 4 days. Tests of lignin, cellulose, and hemicellulose were performed towards the treatments by the Chesson method, while the moisture content test was performed using the AOAC method. Degradation of fermented cocoa shell powder has shown a significant effect on moisture, lignin, cellulose, and hemicellulose contents. Trichoderma viride resulted in the highest lignocellulose degradation compared with the other treatments. The percentage decrease of lignin content is up to $46.69 \mathrm{wt} \%$; while cellulose of $22.59 \mathrm{wt} \%$; and hemicellulose is about $19.41 \mathrm{wt} \%$ from the initial lignin weight.
\end{abstract}

\section{Introduction}

Lignocellulosic residue has now become a concern along with the development of bioeconomy. The biomass with the basis of lignocellulose such as agricultural wastes was considered as a renewable resource that can be promoted for energy through biorefinery [1]. Valorisation of lignocellulose residue such as biorefinery has been recognized as a vital component to support arising bioeconomy by offering a diverse assortment of items from a broad range of biomass sources to fulfil the various requests of the society [2]. According to that, some utilization of various agricultural wastes needs to be addressed in order to enhance the economic, social, and environmental impacts through resources efficiency.

One of the potential agricultural wastes that still underutilized was cocoa shell. Cocoa fruit generally consists of $73.63 \%$ of shell (cocoa pod), $24.37 \%$ of seeds (generally, there are $30-40$ cocoa seeds in one fruit), and $2 \%$ of placenta (wrapping of cocoa seeds) [3]. On the processing of cocoa into chocolate products, cocoa shell needs to be separated from the cocoa. Cocoa shell is a thin, soft, and slightly slimy skin that has been separated from cocoa through the stripping process. Cocoa shell contains high fibre, so when the cocoa shell powder is dissolved, fibre and insoluble compound will settle after a few minute $[4,5]$.

Cocoa shell contains lignin and cellulose that amounted to $18.6 \%$ and $13.7 \%$ [6]. Crude fibre content such as lignocellulose is necessary to be degraded, so it can be digested. Lignocellulose can be degraded through degradation by chemical (basic, acid, solvent, and oxidation), physical (mechanical, thermal, and irradiation), and also biologically (enzymatic and biodegradation), which has been widely used so far [7-9]. While some combinations such as steam explosion, ammonia fibre extraction, and also several novel technologies, i.e., supercritical fluids and ionic liquids, 
developed to make sure that the biocatalysts can access the complex polysaccharides and then convert them to simple sugar [9].

Several combinations of physicochemical and biochemical pretreatment in order for delignification also have been performed and aimed for the better process in resulting in simple sugar from the complex polysaccharides derived from the agricultural wastes. However, some psychochemical pretreatment still used high temperature that needed high energy and utilized acid or base compound that reacted corrosively towards the equipment that resulted high cost and not environment friendly $[10,11]$. Biological pretreatments have been advanced as practical and harmless to the environment options to customary physicochemical treatments, which are costly and risky to the environment [12].

Biodelignification is an appealing methodology on account of its expense adequacy, low energy prerequisite, low climate effect, and low development of poisonous materials such as furfural and hydroxyl methyl furfural [13]. Microbiological delignification is selected as potential and environmentally safe methods for degrading lignocellulose. Mould has a better capability in decomposing lignin, hemicellulose, and cellulose than bacteria which only degrades lignin up to $50 \%[12,14]$. While, white rot mould has been known to have the ability to remove lignin up to $85 \%$ [15]. Trichoderma viride investigated as white rot mould, which is ideal microorganism for cellulose and hemicellulose hydrolysis, show delignification activity up to $56 \%$ that increased the biomass enzymatic degradability [16, 17]. Other moulds such as A. niger, N. sitophila, and Rhizopus sp. also have delignification activities through enzymatic releases such as CMCases, beta-glucosidases, endoglucanase, exoglucanase, pectinases, and xylanases [18].

The hydrolysis of complex components in lignocellulose is closely related to some enzymes involved in the hydrolysis such as cellulose, lignin peroxidase (LiP), manganese peroxidase (MnP), and laccase [19]. Cellulose enzyme resulted by mould is a mixture consisting of three enzymes, namely, endo $\beta$-glucanase, cellobiohydrolase, and $\beta$-glucosidase, which work synergistically in hydrolyze crystallized cellulose to glucose [20]. Trichoderma viride can produce large amounts of endoglucanase, while $A$. niger produces a cellulose enzyme containing $\beta$-glucosidase, yet low in exo and endoglucanase [21]. In addition to $T$. viride and $A$. niger, $N$. sitophila has high cellulolytic and hemicellulose activities in fermentation to produce simple sugars [22]. N. sitophila is strong amylolytic by $\alpha$-amylase and glucoamylase enzymes production, yet inadequate in its lipolytic and proteolytic properties, while Rhizopus oryzae produce carbohydrate degrading enzymes such as amylase, cellulase, xylanase, and glucoamylase [23]. Endoglucanase is an enzyme that attacks amorphous part of crude fibre, whereas $\beta$-glucosidase is an enzyme that converts cellobiohydrolase and oligosaccharide into glucose [24]. Amorphous portion of crude fibre hydrolyzed by endoglucanase will pave the way for cellobiohydrolase; however when cellobiose is accumulated in substrate, endoglucanase activity will be inhibited [25]. The purpose of this study is to obtain the right mould in degrading cocoa shells lignocellulose.

\section{Materials and Methods}

Dried cocoa (Theobroma cacao L.) obtained from a private plantation in West Java, Aspergillus niger and Trichoderma viride obtained from Microbiology Laboratory, Faculty of Mathematic and Natural Science, Padjadjaran University, and Rhizopus oryzae and Neurospora sitophila obtained from Microbiology Laboratory, School of Life Science and Technology, Institut Teknologi Bandung. Mould isolates were propagated for 3 days at optimum temperature of mould on in potato dextrose broth/PDB (Oxoid). The temperature used for propagation and fermentation was the optimum temperature of each mould, i.e., $35^{\circ} \mathrm{C}$ for $A$. niger and $30^{\circ} \mathrm{C}$ for $T$. viride, R. oryzae, and N. sitophila. After propagation, the mould isolates were then enriched for 5 (five) days on PDB until it reached $10^{8}$ colonies $/ \mathrm{ml}$.

Cocoa shell was ground into cocoa shell powder, sieved with a 60-mesh sieve, and then sterilized using an autoclave at $121^{\circ} \mathrm{C}$ for 15 minutes. The sterile substrates were then inoculated with the mould isolates (A. niger, T. viride, $R$. oryzae, and $N$. sitophila) and incubated for 5 days at the temperature of $30^{\circ} \mathrm{C}$ (T. viride, $R$. oryzae, and $N$. sitophila) and $35^{\circ} \mathrm{C}(A$. niger $)$. After fermentation, the result was then dried at $50^{\circ} \mathrm{C}$ for 4 days, and the dried cocoa shell powder was milled and tested. Moisture contents were tested by the AOAC method; meanwhile, lignin, cellulose, and hemicellulose were tested by the Chesson method; then, the microstructure was tested with a scanning electron microscope.

2.1. Moisture Content Tests. Two empty dishes dried on an oven with the temperature of $105^{\circ} \mathrm{C}$ for 1 hour, cooled for 15 minutes, and then weighed until constant (Mi). Two grams of samples were prepared and put into the dish and dried at the temperature of $105^{\circ} \mathrm{C}$ for 1 hour, cooled for 15 minutes, then weighed until constant (Mf), and calculated using the following equation:

$$
\% \text { moisture }=\frac{\mathrm{Mi}-\mathrm{Mf}}{\mathrm{Mi}} \times 100 \text { weight } \mathrm{B}-\text { weight } \mathrm{C} \times 100 \% \text { weight } \mathrm{A} .
$$

2.2. Lignin, Cellulose, and Hemicellulose Tests. Eight sheets of $90 \mathrm{~mm}$ Whatman filter paper were placed in an oven at $105^{\circ} \mathrm{C}$ for 1 hour and then cooled in a desiccator for 15 minutes. The filter paper was weighed until a constant weight was obtained. Two porcelain dishes were put into the furnace at a temperature of $600^{\circ} \mathrm{C}$ for 60 minutes and then 
cooled in a desiccator for 30 minutes. The porcelain dish was weighed until a constant weight was obtained. Two sheets of constant filter paper were folded and put into a constant porcelain dish and then ashed in a furnace at $600^{\circ} \mathrm{C}$ for 3 hours. The weight of the filter paper ash was weighed and recorded, and then, the constant filter paper ash content was calculated.

One gram of sample (weight A) was put into an Erlenmeyer flask and added $75 \mathrm{ml}$ of $\mathrm{H}_{2} \mathrm{O}$ and then refluxed at $1000^{\circ} \mathrm{C}$ in a waterbath for 1 hour. The reflux result was filtered with constant filter paper, and the residue was washed with $300 \mathrm{ml}$ of hot water. The residue was dried in an oven at $105^{\circ} \mathrm{C}$ for 1 hour, cooled in a desiccator for 15 minutes, and then weighed until a constant weight (weight B) was obtained. The residue was put into an erlenmeyer and added $75 \mathrm{ml}$ of $\mathrm{H}_{2} \mathrm{SO}_{4} 1 \mathrm{~N}$ (Merck), and refluxed in a waterbath for 1 hour at $100^{\circ} \mathrm{C}$. The results were filtered and washed until neutral with $300 \mathrm{ml}$ of hot water. The residue was dried in an oven at $105^{\circ} \mathrm{C}$ for 1 hour, cooled in a desiccator for 15 minutes, and then weighed until a constant weight (weight $\mathrm{C}$ ) was obtained. The dry residue was added $50 \mathrm{ml}$ of $\mathrm{H}_{2} \mathrm{SO}_{4} 72 \%$ and soaked at room temperature for 4 hours. The residue was added with $75 \mathrm{ml}$ of $1 \mathrm{~N} \mathrm{H}_{2} \mathrm{SO}_{4}$ and refluxed at $100^{\circ} \mathrm{C}$ in a waterbath for 1 hour. The residue was filtered and washed with $400 \mathrm{ml}$ hot water until neutral. The residue was heated in an oven at $100^{\circ} \mathrm{C}$ for 1 hour and cooled in a desiccator for 15 minutes, repeated until the weight was constant and reweighed (weight $\mathrm{D}$ ). The residue was ashed along with the filter paper in a furnace at $600^{\circ} \mathrm{C}$ for 5 hours. The weight of residual ash and filter paper was weighed, reduced by the constant weight of filter paper (weight $\mathrm{E}$ ) and recorded, and then, the ash content was calculated using the following equations:

$$
\begin{aligned}
\text { Hemicellulose }(w t \%) & =\frac{(\text { weight } \mathrm{B}-\text { weight } \mathrm{C}) \times 100 \%}{\text { weight } \mathrm{A}}, \\
\text { Cellulose }(w t \%) & =\frac{(\text { weight } \mathrm{C}-\text { weight } \mathrm{D}) \times 100 \%}{\text { weight } \mathrm{A}}, \\
\text { Lignin }(w t \%) & =\frac{(\text { weight } \mathrm{D}-\text { weight } \mathrm{E}) \times 100 \%}{\text { weight } \mathrm{A}} .
\end{aligned}
$$

2.3. Microstructure Tests. Samples were coated by aluminium-palladium and affixed by carbon tape and then mounted. Sample surface height and the holder were adjusted and then tightened. The electron microscope (JEOL JSM-6360LA) was used to visualize at $10 \mathrm{kV}$ of acceleration voltage [26].

2.4. Statistical Analysis. The study was done using experimental methods using completely randomized design (CRD) with 4 (four) treatments of different kinds of mould (Trichoderma viride, Neurospora sitophila, Rhizopus oryzae, and Aspergillus niger) with 4 (four) replicates. The data were analysed with analysis of variance (ANOVA) to determine the significance of the treatment applied and followed by the Duncan test to identify the difference among the treatments.

\section{Results and Discussion}

3.1. Moisture Contents Identification. Moisture contents have a significant different effect due to the mechanism of respiration and hydrolysis of lignocellulose by mould. The high moisture content produced may be due to accumulation of water from the cellular respiration mechanism and the low heat transfer on substrate, so evaporation rate tends to be low and results in water contained in substrate as well metabolite yield accumulated in the system and increasing moisture content of material [27]. Low moisture content is caused by hydrolysis of lignocellulose component by enzyme that require large amounts of water, although it produced water as a byproduct of respiration, yet it required more water to degrade lignocellulose compared to water produced by respiratory of byproduct [28].

A. niger, N. sitophila, and T. viride used water to produce secondary metabolite which is enzyme, whereas $R$. oryzae used water to supply the need of primary metabolite respiratory, so that water needs of $R$. oryzae was much more than other moulds. Decrease in moisture content can be due to changes of catabolic heat on substrate surface that causes water evaporation from inside to outside of the system. Overall moisture content of degraded cocoa shell was $4.11 \%-4.52 \%$. According to the Indonesian National Standard, water content of cocoa shell is maximum of 5\%. So, in this study, cocoa shell powder has fulfilled the moisture content requirement; on the other hand, it showed that cocoa shell powder was dried enough, so it can be stored in long term and does not require particular treatment. It can be stored in sealed container at room temperature to avoid mechanical damage and moisture absorption from surrounding environment [29]. If the moisture content is known, then it can be adjusted to storage condition to minimize the capability of microorganism growth after the fermentation process stopped.

3.2. Lignin Degradation of Cocoa Shell. Based on the result of ANOVA, mould addition gave a significant effect towards lignin content of cocoa shell (Table 1). Lignin prevents the entry of enzyme in hydrolyze polysaccharides into monosaccharides. Lignin binds hemicellulose and cellulose and forms a layer as anchoring from penetration of solution [14]. In this study, lignin content has a significantly different effect because each mould has different abilities to degrade lignin depending on the production of extracellular enzyme.

Cocoa shell powder fermented by $T$. viride has the lowest lignin content than other treatments. T. viride could reduce lignin content from $17.20 \%$ to $9.17 \%$, which means a decrease in lignin content by T. viride reached $46.59 \%$ on cocoa shell powder. $T$. viride is white decaying fungi that can degrade lignin of in wheat up to $56 \%$ by producing lignindegrading enzyme [16]. According to Saili et al. (2014), most of Trichoderma-type moulds produce polyphenol oxidase to degrade lignin. 
TABLE 1: Characteristics of cocoa shell.

\begin{tabular}{|c|c|c|c|c|}
\hline Treatment & Moisture (wt\%) & Lignin (wt\%) & Cellulose (wt\%) & Hemicellulose (wt\%) \\
\hline Cocoa shell & 13.67 & 17.20 & 31.87 & 48.26 \\
\hline Trichoderma viride & $4.52^{\mathrm{b}}$ & $9.17^{\mathrm{a}}$ & $24.67^{\mathrm{a}}$ & $38.89^{\mathrm{a}}$ \\
\hline Neurospora sitophila & $4.46^{\mathrm{b}}$ & $12.24^{\mathrm{b}}$ & $25.46^{\mathrm{b}}$ & $40.27^{\mathrm{b}}$ \\
\hline Aspergillus niger & $4.42^{\mathrm{b}}$ & $15.02^{\mathrm{c}}$ & $27.60^{c}$ & $42.38^{\mathrm{c}}$ \\
\hline Rhizopus oryzae & $4.11^{\mathrm{a}}$ & $16.47^{\mathrm{d}}$ & $29.77^{\mathrm{d}}$ & $45.24^{\mathrm{d}}$ \\
\hline
\end{tabular}

Treatment marked with the same letter showed no significant difference at $5 \%$ level according to the Duncan test.

A decrease of lignin with fermentation treatment of N. sitophila was lower than T. viride which is about $28.84 \%$. $N$. sitophila can reduce lignin level up to $25 \%$ by producing laccase enzyme [30]. In the lignin degradation process, laccase oxidizes phenol to be phenoxyl. A decrease in lignin level by $A$. niger was $15.02 \%$, which means only $12.67 \%$ from the initial lignin content. In accordance with Silva et al. (2010), Aspergillus sp. can degrade lignin up to $26.5 \%$ by producing high number of laccase.

Based on Table 1, R. oryzae could reduce lignin level about $4.24 \%$ from initial lignin content, where decrease by this mould showed lower percentage than other three moulds. According to Viji and Neelanarayanan (2015), lignin degradation by $R$. oryzae can reach $23.8 \%$ in rice straw, which is the lowest if compared with other moulds such as $A$. oryzae that can reduce lignin level to $52 \%$, A. fumigatus of $58 \%$, and mix culture of $R$. oryzae, A. oryzae, and $A$. fumigatus of $93.8 \%$. It showed that treatment with R. oryzae and Aspergillus can reduce lignin level. However, the mix culture can result in higher decreasing percentage of lignin level.

$R$. oryzae type moulds generally produce more cellulose enzymes, hemicellulose, pectinase, amylase, protease, and lipase, but some of them can produce tyrosinase and peroxidase to hydrolyze lignin such as ENHE type of $R$. oryzae [31]. Highest lignin degradation was resulted using Basidiomycetes types such as white rot fungi, brown rot fungi, and soft rot fungi. A. niger, $N$. sitophila, and T. viride are included in soft rot fungi class because $A$. niger and $N$. sitophila are microfungi from phylum Ascomycotina and $T$. viride is microfungi from subphylum Deuteromycota [32].

3.3. Cellulose Degradation of Cocoa Shell. Based on the result of ANOVA, mould addition treatment gave a significant effect towards cellulose content of cocoa shell. In this study, cellulose content presented a significantly different effect because the capability of mould in degrading cellulose is varying. T. viride succeeded in decreasing cellulose level of cocoa shell to $22.59 \%$ of total initial cellulose. Trichoderma produces endoglucanase to degrade cellulose up to $20 \%$ [33]. $T$. viride is a type of mould that can destroy high level of cellulose and capable to synthesize several essential factors to dissolve a strongly bonded cellulose with hydrogen bond [34]. The bonded cellulose is converted to glucose and simple sugars by using cellulose enzyme produced by the mould [21].

The superiority of $T$. viride as a producer of cellulose enzyme is due to its capability to produce complete cellulose required to hydrolyze crystalline cellulose [35]. The mycelium of the mould can produce variety of enzymes, including cellulose and chitinase enzymes. Mould generally has cellulose because of its habitat in organic materials containing cellulose. Cellulose consists of endo- $\beta$-1,4-glucanase, exo$\beta$-1,4- glucanase, and $\beta$-1,4 glucosidase (cellobiase), which can be produced by $T$. viride [36].

All of these enzymes are hydrolytic and work either consecutively or simultaneously. Cellobiohydrolase is an enzyme that has affinity towards high level of cellulose capable of breaking crystalline cellulose, whereas endoglucanase acts on amorphous cellulose [37]. Cellobiohydrolase shatters cellulose by cutting the hydrogen bonds that cause the glucose chains to be readily hydrolyzed. Further hydrolysis is carried out by $\beta$-glucanase and $\beta$-glucosidase, resulting in glucose.

$N$. sitophila could degrade cellulose to $20.11 \%$, whereas A. niger degrade cellulose up to $13.39 \%$ of initial cellulose. Neurospora sp. utilizes existing carbon compound in rice and wheat husk to produce cellulose enzyme, while Aspergillus sp. utilizes ammonium salt to produce cellulose enzyme $[38,39]$. A niger produce cellulose enzyme containing many $\beta$-glucosidase, yet low exo and endoglucanase [40]. N. sitophila under optimum condition can produce cellulose enzyme (endoglucanase, exoglucanase, and $\beta$-glucosidase) at $35^{\circ} \mathrm{C}$ and $\mathrm{pH} 5$ on banana substrates [41].

Treatment of $R$. oryzae results in a low decrease of cellulose level since it can only reduce cellulose level from $31.87 \%$ to $29.77 \%$, which means only $6.59 \%$ of initial cellulose. $R$. oryzae provides endoglucanase and exoglucanase on certain substrates to degrade cellulose (Ghosh and Rani Ray, 2011). R. oryzae can produce a relative high level of exoglucanase within a short time from dried flower and lemon peel by utilizing the substrate as a carbon source [42]. This statement is supported by Viji and Neelanarayanan (2015), which states $R$. oryzae can degrade cellulose up to $16.74 \%$ in rice husk. Cellulose degradation by $R$. oryzae is the lowest, since $R$. oryzae can only produce endoglucanase and exoglucanase, while other moulds may also produce $\beta$-glucosidase.

3.4. Hemicellulose Degradation of Cocoa Shell. Based on the result of ANOVA, the moulds treatment significantly affected hemicellulose content of cocoa shell. Hemicellulose content gave a significantly different effect due to the varying abilities of mould to degrade hemicellulose and cellulose hydrolysis. One of the most widely studied hemicellulosedegrading enzymes is xylanase $[34,43]$. Xylanase is an 


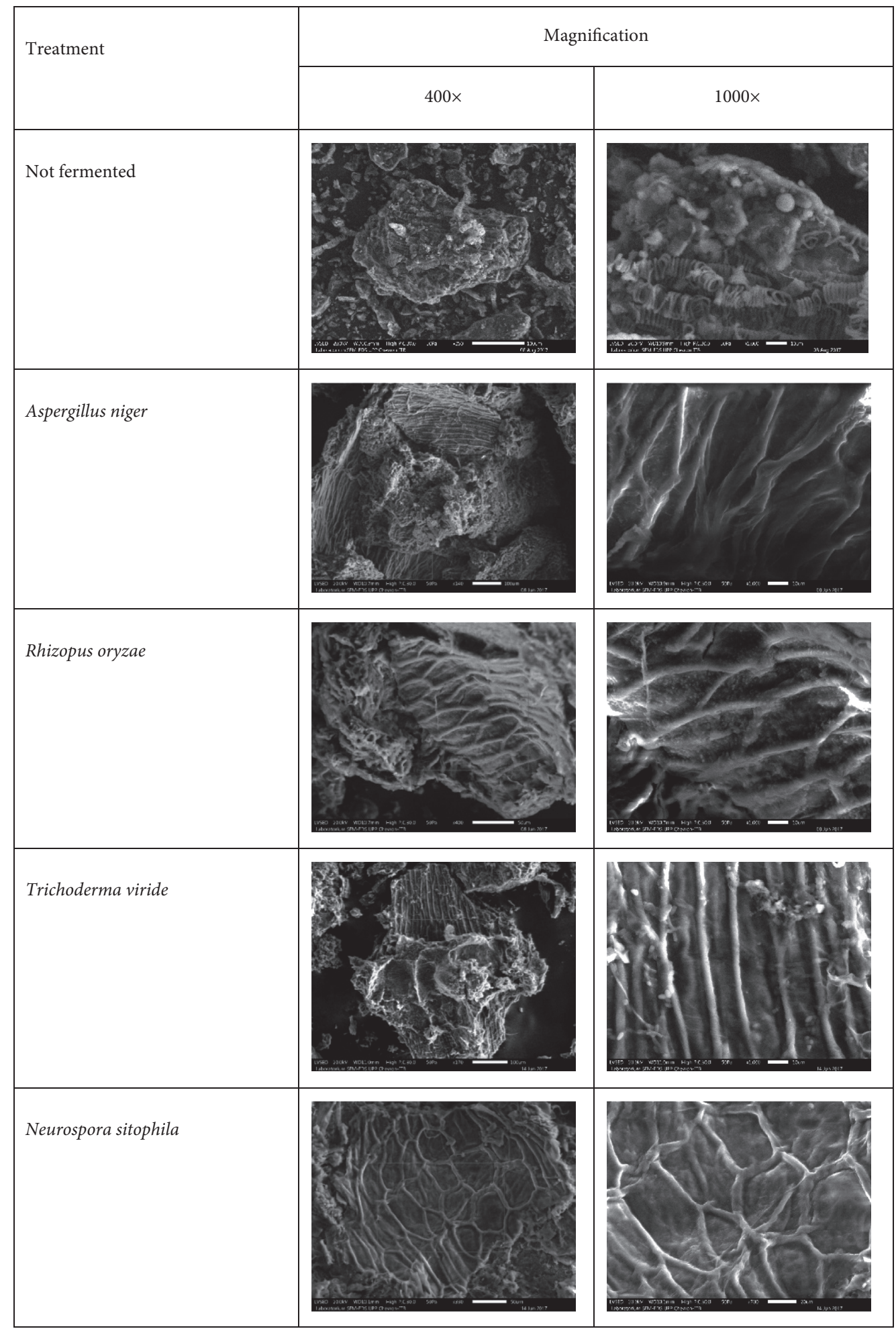

FIgURE 1: Microstructure of cocoa shell powder.

enzyme that catalyzes the hydrolysis bond on xylan which is one of the principal constituents in hemicellulose [44]. Endo-1,4- $\beta$-xylanase cuts the glycosidic bond on xylan backbone and reduces the degree of substrate polymerization. Xylan is not attacked randomly; however, the bond chosen for hydrolysis depends on the nature of substrate molecule such as length of the chain, degree of branching, and the presence of substituents [45].

Xylanase is widely produced by microorganism such as Trichoderma sp. and Aspergillus sp. [46]. In addition, T. viride also produces all xylanolytic enzymes [47]. Based on results, the treatments of $T$. viride and A. niger reduced 
hemicellulose contents, respectively, $19.42 \%$ and $12.18 \%$ from initial hemicellulose of cocoa shell. According to [48], $N$. sitophila has capability of cellulolytic and hemicellulolytic activities on fermentation process to produce simple sugars. N. sitophila grows normally on substrates containing only carbon sources, organic salts, and biotin. The carbon sources are mono-, di-, or polysaccharides. According to the statement, hemicellulose contents of N. sitophila treatment of $40.27 \%$ decreased $16.56 \%$ from initial hemicellulose.

In accordance with [49], Rhizopus sp. produces endo and exopolygalacturonase enzyme to degrade hemicellulose. Based on the results of hemicellulose contents known, R. oryzae treatment reduced hemicellulose level from $48.26 \%$ to $45.24 \%$, which is $6.26 \%$ decreased. The low degradation of hemicellulose may be caused by hemicellulose content in cocoa shell that contains low galacturonan. Polygalacturonase, one of pectin class enzymes, plays a role in the process of ripening fruit naturally [50].

3.5. Microstructure of Treated Cocoa Shell Powder. Based on Figure 1, there was a difference on surface of initial cocoa shell that has not been fermented by mould, where it still had dense and complex lignocellulose structure, while on the surface of fermented cocoa shell was more tenuous in the structure. Dense arrangement of structure indicates cocoa shell has high lignocellulosic level. Surface of cocoa shell is a nonuniform particle which exhibits lignocellulose composed of various compounds, namely, lignin, cellulose, hemicellulose, and other compounds such as pectin and polyphenol [51].

Each treatment showed different degradation effects, as shown in Figure 1. Lignocellulose structure of cocoa shell which has been delignified by $N$. sitophila and $R$. oryzae has similar structure; however, structure of cocoa shell treated by $N$. sitophila tends to remain mutually binding with tenuous distance, while the structure of cocoa shell treated by T. viride has similar structure of cocoa shell treated by A. niger. Lignocellulose structure of cocoa shell treated by T. viride tends not bind and has tenuous distance compared to $A$. niger which tends to be linked to each other. It may be due to the difference in the capability of extracellular enzyme produced by mould to break lignin bonds against cellulose and hemicellulose.

The tenuous and discontinuous lignocellulose structure of $T$. viride treatment is caused by enzymes activity either successively or at the same time degrading lignin, cellulose, and hemicellulose bonds. Cellobiohydrolase enzyme produced by T. viride is able to break down part of crystalline cellulose, whereas endoglucanase acts on cellulose amorphous [24]. Cellobiohydrolase breaks down cellulose by cutting the hydrogen bonds that cause glucose chains to be readily hydrolyzed. Further hydrolysis is carried out by $\beta$-glucanase and $\beta$-glucosidase, thus producing glucose.

Lignocellulose structure that tends to bind to treatment of $A$. niger and N. sitophila is caused by the work of less optimal laccase enzyme. Laccase has ability to break $\alpha$ and $\beta$-carbon bonds in lignin (Janusz et al., 2017). Dense structure is due to low endoglucosidase enzyme produced by A. niger so that amorphous portion of cellulose is still formed, in contrast to lignocellulose structure treated by $N$. sitophila that has tenuous structure because $N$. sitophila produce higher endoglucosidase, so amorphous part of cellulose was split [52]. The lignocellulose structure of $R$. oryzae treatment that binds and tends to be denser than lignocellulose structure of $N$. sitophila treatment caused by enzymes produced by $R$. oryzae is less able to degrade lignin, cellulose, and hemicellulose.

In accordance with [53], cellulose and hemicellulose cannot be converted directly because it is associated with lignin, so the structure is tight. When mould produces extracellular enzyme, cellulose and hemicellulose bonds with lignin can be disconnected within lignin itself. The disconnected bond was hydrogen bond between cellulose and lignin or hemicellulose and bonds between lignin and hemicellulose in the form of an ether or ester group. The extracellular enzyme produced may also break the bonds in lignin compound comprising the ether group and carbon bonds into lignin fragments [54]. The activity of lignocellulosic enzyme also leads to bond breaking in lignin compound that causes lignin to be degraded. Lignin degradation is started by attacking hydrogen atom attached on the phenolic group by hydroxyl ion.

\section{Conclusions}

Fermentation of cocoa shell powder by Aspergillus niger, Rhizopus oryzae, Trichoderma viride, and Neurospora sitophila has a significantly different effect on lignin, cellulose, and hemicellulose contents and then no significant difference at moisture content on T. viride, $N$. sitophila, and A. niger. Trichoderma viride were mould which show highest cocoa shell-degrading ability with percentage of decrease of lignin, cellulose, and hemicellulose level of $46.69 \%, 22.59 \%$, and $19.42 \%$ respectively. Neurospora sitophila degraded lignin of $28.84 \%$, cellulose of $20.11 \%$, and hemicellulose of $16.56 \%$, A. niger degraded lignin of $12.67 \%$, cellulose of $13.39 \%$, and hemicellulose of $12.18 \%$, while $R$. oryzae degraded lignin, cellulose, and hemicellulose of $4.24 \%, 6.59 \%$, and $6.26 \%$, respectively.

Cocoa shell powder fermented by Trichoderma viride is potent as alternative source that is possible to be mixed with the main raw material for cocoa powder production. High number percentage of lignin, cellulose, and hemicellulose that degraded by fermentation processes resulting in potential cocoa shell powder that shown digestible characteristics that can be identified further. Delignification of cocoa shell powder by Trichoderma viride has shown the effectiveness of lignocellulose waste pretreatments which can be a source of new raw materials that can maximize the utilization of cocoa shell.

\section{Data Availability}

The data used to support this study are included within the article. 


\section{Conflicts of Interest}

The authors declare that they have no conflicts of interest.

\section{Acknowledgments}

The authors thank the Laboratory of Food Microbiology, Department of Food Industrial Technology, Faculty Agroindustrial Technology, Universitas Padjadjaran, and also thank the Directorate of Research, Community Services of Universitas Padjadjaran for funding the research and publication through the scheme of "Hibah Internal Unpad."

\section{References}

[1] P. Manzanares, "The role of biorefinering research in the development of a modern bioeconomy," Acta Innovations, vol. 37, pp. 47-56, 2020.

[2] M. Hingsamer and G. Jungmeier, "Chapter five-biorefineries," in The Role of Bioenergy in the Bioeconomy, C. Lago, N. Caldés, and Y. Lechón, Eds., Academic Press, Cambridge, MA, USA, 2019.

[3] W. El Kiyat, A. Monica, N. Qomariyah, and B. S. Manurung, "Enzymes involving in chocolate processing," Journal of Food and Pharmaceutical Sciences, vol. 6, pp. 1-6, 2018.

[4] M. Djali, I. S. Setiasih, and T. S. Rindiantika, "Chemical characteristics, phytochemicals and cacao shell toxicity changes during the processing of cocoa beans," Asian Journal of Agriculture and Biology, vol. 6, no. 1, pp. 103-114, 2018.

[5] J. Panak Balentić, Đ Ačkar, S. Jokić, A. Jozinović, J. Babić, and B. Miličević, "Cocoa shell: a by-product with great potential for wide application," Molecules, vol. 23, no. 6, p. 1404, 2018.

[6] O. J. Makinde, S. A. Okunade, E. Opoola, A. B. Sikiru, S. O. Ajide, and S. Elaigwu, "Exploration of Cocoa $(<\mathrm{em}>$ Theobroma $\mathrm{Cacao}</ \mathrm{em}>)$ by-products as valuable potential resources in livestock feeds and feeding systems," Theobroma Cacao-Deploying Science for Sustainability of Global Cocoa Economy, Intech Open, London, UK, 2019.

[7] D. Kim, "Physico-chemical conversion of lignocellulose: inhibitor effects and detoxification strategies: a mini review," Molecules, vol. 23, no. 2, p. 309, 2018.

[8] G. L. Utama, F. E. E. Sidabutar, H. Felina, D. W. Wira, and R. L. Balia, "The utilization of fruit and vegetable wastes for bioethanol production with the inoculation of indigenous yeasts consortium," Bulgarian Journal of Agricultural Science, vol. 25, no. 2, pp. 264-270, 2019.

[9] M. H. L. Silveira, A. R. C. Morais, A. M. da Costa Lopes et al., "Current pretreatment technologies for the development of cellulosic ethanol and biorefineries," ChemSusChem, vol. 8, no. 20, pp. 3366-3390, 2015.

[10] C. Darsih, S. K. Wahono, V. T. Rosyida, and M. Kismurtono, "White rot fungus (marasmius sp.) delignification on sugarcane bagasse for bioethanol production," in Proceeding ISETHMuhammadiyah University Press, Yogyakarta, Indonesia, 2015.

[11] M. Taylor, H. Alabdrabalameer, and V. Skoulou, "Choosing physical, physicochemical and chemical methods of pretreating lignocellulosic wastes to repurpose into solid fuels," Sustainability, vol. 11, no. 13, p. 3604, 2019.

[12] A. D. Moreno, D. Ibarra, P. Alvira, E. Tomás-Pejó, and M. Ballesteros, "A review of biological delignification and detoxification methods for lignocellulosic bioethanol production," Critical Reviews in Biotechnology, vol. 35, no. 3, pp. 342-354, 2015.

[13] B. Semeraro, D. Summa, S. Costa, F. Zappaterra, and E. Tamburini, "Bio-delignification of green waste $(\mathrm{GW})$ in Codigestion with the organic fraction of municipal solid waste (OFMSW) to enhance biogas production," Applied Sciences, vol. 11, no. 13, p. 6061, 2021.

[14] G. Janusz, A. Pawlik, J. Sulej, U. Świderska-Burek, A. JaroszWilkołazka, and A. Paszczyński, "Lignin degradation: microorganisms, enzymes involved, genomes analysis and evolution," FEMS Microbiology Reviews, vol. 41, no. 6, pp. 941-962, 2017.

[15] W. Wang, T. Yuan, B. Cui, and Y. Dai, "Investigating lignin and hemicellulose in white rot fungus-pretreated wood that affect enzymatic hydrolysis," Bioresource Technology, vol. 134, pp. 381-385, 2013.

[16] F. Ghorbani, M. Karimi, D. Biria, H. R. Kariminia, and A. Jeihanipour, "Enhancement of fungal delignification of rice straw by Trichoderma viride sp. to improve its saccharification," Biochemical Engineering Journal, vol. 101, pp. 77-84, 2015.

[17] M. Madadi and A. Abbas, "Lignin degradation by fungal pretreatment: a review," Journal of Plant Pathology \& Microbiology, vol. 8, no. 2, 2017.

[18] Y. S. M. Godliving, "Lignocellulolytic enzymes from tropical fungi: types, substrates and applications," Scientific Research and Essays, vol. 7, no. 15, 2012.

[19] M. Vrsanska, S. Voberkova, V. Langer, D. Palovcikova, A. Moulick, and V. Adam, "Induction of laccase, lignin peroxidase and manganese peroxidase activities in white-rot fungi using copper complexes," Molecules, vol. 21, no. 11, 2016.

[20] P. Tiwari, B. N. Misra, and N. S. Sangwan, " $\beta$-Glucosidases from the fungus Trichoderma: an efficient cellulase machinery in biotechnological applications," BioMed Research International, vol. 2013, Article ID 203735, 10 pages, 2013.

[21] S. Sajith, S. Sreedevi, and S. Benjamin, "An overview on fungal cellulases with an industrial perspective," Journal of Nutrition \& Food Sciences, vol. 6, no. 1, 2016.

[22] J. C. Waters, A. Nixon, M. Dwyer, J. C. Biffinger, and K. Lee, "Developing elite Neurospora crassa strains for cellulosic ethanol production using fungal breeding," Journal of Industrial Microbiology and Biotechnology, vol. 44, no. 8, pp. 1137-1144, 2017.

[23] B. J. Green and D. H. Beezhold, "Industrial fungal enzymes: an occupational allergen perspective," Journal of Allergy, vol. 2011, Article ID 682574, 11 pages, 2011.

[24] S. Jayasekara and R. Ratnayake, "Microbial cellulases: an overview and applications," Cellulose, Intech Open, London, UK, 2019.

[25] N. Szijártó, M. Siika-aho, M. Tenkanen et al., "Hydrolysis of amorphous and crystalline cellulose by heterologously produced cellulases of Melanocarpus albomyces," Journal of Biotechnology, vol. 136, no. 3-4, pp. 140-147, 2008.

[26] G. L. Utama, C. Dio, J. Sulistiyo, F. Yee Chye, E. Lembong, and Y. Cahyana, "Evaluating comparative $\beta$-glucan production aptitude of Saccharomyces cerevisiae, Aspergillus oryzae, Xanthomonas campestris, and Bacillus natto," Saudi Journal of Biological Sciences, vol. 28, no. 12, 2021.

[27] F. M. DaMatta and J. D. C. Ramalho, "Impacts of drought and temperature stress on coffee physiology and production: a review," Brazilian Journal of Plant Physiology, vol. 18, no. 1, pp. 55-81, 2006. 
[28] L. J. Jönsson, B. Alriksson, and N. O. Nilvebrant, "Bioconversion of lignocellulose: inhibitors and detoxification," Biotechnology for Biofuels, vol. 6, p. 16, 2013.

[29] A. Conte, L. Angiolillo, M. Mastromatteo, and M. A. D. Nobile, "Technological options of packaging to control food quality," in Food Industry, Wiley, Hoboken, NJ, USA, 2013, https://www.intechopen.com/chapters/41669.

[30] B. Viswanath, B. Rajesh, A. Janardhan, A. P. Kumar, and G. Narasimha, "Fungal laccases and their applications in bioremediation," Enzyme Research, vol. 2014, Article ID 163242, 21 pages, 2014.

[31] B. Ghosh and R. Rani Ray, "Current commercial perspective of Rhizopus oryzae: a review," Journal of Applied Sciences, vol. 11, no. 14, pp. 2470-2486, 2011.

[32] A. K. Gautam, S. Sharma, S. Avasthi, and R. Bhadauria, "Diversity, pathogenicity and toxicology of A. niger: an important spoilage fungi," Research Journal of Microbiology, vol. 6, no. 3, pp. 270-280, 2011.

[33] S. Pandey, M. Srivastava, M. Shahid, V. Kumar, A. Singh, and S. Trivedi, "Trichoderma species cellulases produced by solid state fermentation," Journal of Data Mining in Genomics \& Proteomics, vol. 6, no. 2, 2015.

[34] B. Yang, Z. Dai, S.-Y. Ding, and C. E. Wyman, "Enzymatic hydrolysis of cellulosic biomass," Biofuels, vol. 2, no. 4, pp. 421-449, 2011.

[35] A. V. Gusakov, "Alternatives to Trichoderma reesei in biofuel production," Trends in Biotechnology, vol. 29, no. 9, pp. 419-425, 2011.

[36] X.-h. Li, H.-j. Yang, B. Roy et al., "Enhanced cellulase production of the Trichoderma viride mutated by microwave and ultraviolet," Microbiological Research, vol. 165, no. 3, pp. 190-198, 2010.

[37] K. Kipper, P. Väljamäe, and G. Johansson, "Processive action of cellobiohydrolase Cel7A from Trichoderma reesei is revealed as "burst" kinetics on fluorescent polymeric model substrates," Biochemical Journal, vol. 385, no. Pt 2, pp. 527-535, 2005.

[38] Y. Xiong, S. T. Coradetti, X. Li et al., "The proteome and phosphoproteome of Neurospora crassa in response to cellulose, sucrose and carbon starvation," Fungal Genetics and Biology, vol. 72, pp. 21-33, 2014.

[39] E. M. Obeng, S. N. N. Adam, C. Budiman, C. M. Ongkudon, R. Maas, and J. Jose, "Lignocellulases: a review of emerging and developing enzymes, systems, and practices," Bioresources and Bioprocessing, vol. 4, no. 1, p. 16, 2017.

[40] M. Sohail, R. Siddiqi, A. Ahmad, and S. A. Khan, "Cellulase production from Aspergillus Niger MS82: effect of temperature and pH," New Biotech, vol. 25, no. 6, pp. 437-441, 2009.

[41] M. Asad, M. Asgher, M. A. Sheikh, and J. I. Sultan, "Production of Neurospora sitophila cellulases in solid state cultures," Journal of the Chemical Society of Pakistan, vol. 28, no. 6, pp. 590-595, 2006.

[42] S. Mukherjee, M. Karmakar, and R. Rani Ray, "Production of extra cellular exoglucanase by Rhizopus oryzae from submerged fermentation of Agro wastes," Recent Research in Science and Technology, vol. 3, no. 3, pp. 69-75, 2011.

[43] C. Álvarez, F. M. Reyes-Sosa, and B. Díez, "Enzymatic hydrolysis of biomass from wood," Microbial biotechnology, vol. 9, no. 2, pp. 149-156, 2016.

[44] S. K. Promon, W. Kamal, S. S. Rahman, M. M. Hossain, and N. Choudhury, "Bioethanol production using vegetable peels medium and the effective role of cellulolytic bacterial (Bacillus subtilis) pre-treatment," F1000Res, vol. 7, 2018.
[45] V. K. Gupta, Microbial Enzymes in Bioconversions of Biomass, Springer, Berlin, Germany, 2016.

[46] S. Raveendran, B. Parameswaran, S. B. Ummalyma et al., "Applications of microbial enzymes in Food industry," Food Technology and Biotechnology, vol. 56, no. 1, pp. 16-30, 2018.

[47] D. Fortkamp and A. Knob, "High xylanase production by Trichoderma viride using pineapple peel as substrate and its apllication in pulp biobleaching," African Journal of Biotechnology, vol. 13, no. 22, pp. 2248-2259, 2014.

[48] A. Shah, H. Patel, and M. Narra, "Bioproduction of fungal cellulases and hemicellulases through solid state fermentation," in Fungal Metabolites, J.-M. Mérillon and K. G. Ramawat, Eds., Springer International Publishing, Cham. Switzerland, 2017.

[49] J. van den Brink and R. P. de Vries, "Fungal enzyme sets for plant polysaccharide degradation," Applied Microbiology and Biotechnology, vol. 91, no. 6, pp. 1477-1492, 2011.

[50] C. Verma, A. K. M. Tiwari, and S. Mishra, "Biochemical and molecular characterization of cell wall degrading enzyme, pectin methylesterase versus banana ripening: an overview," Asian Journal of Biotechnology, vol. 9, no. 1, pp. 1-23, 2017.

[51] Z. Daud, A. S. M. Kasim, A. M. Aripin, H. Awang, and M. Z. M. Hatta, "Chemical composition and morphological of cocoa pod husks and cassava peels for pulp and paper production," Australian Journal of Basic and Applied Science, vol. 7, no. 9, pp. 406-411, 2013.

[52] H. V. Lee, S. B. A. Hamid, and S. K. Zain, "Conversion of lignocellulosic biomass to nanocellulose: structure and chemical process," Science World Journal, vol. 2014, Article ID 631013, 20 pages, 2014.

[53] N. Sorek, T. H. Yeats, H. Szemenyei, H. Youngs, and C. R. Somerville, "The implications of lignocellulosic biomass chemical composition for the production of advanced biofuels," BioScience, vol. 64, no. 3, pp. 192-201, 2014.

[54] J. D. Gargulak, S. E. Lebo, and T. J. McNally, "Lignin," in KirkOthmer Encyclopedia of Chemical TechnologyAmerican Cancer Society, Atlanta, GO, USA, 2015. 